Article

\title{
Sustainability Reporting in Family Firms: A Panel Data Analysis
}

\author{
Giovanna Gavana ${ }^{1}$, Pietro Gottardo ${ }^{2}$ and Anna Maria Moisello ${ }^{2, *}$ \\ 1 Department of Economics, University of Insubria, 21100 Varese VA, Italy; giovanna.gavana@uninsubria.it \\ 2 Department of Economics and Management, University of Pavia, 27100 Pavia PV, Italy; \\ pietro.gottardo@unipv.it \\ * Correspondence: annamaria.moisello@unipv.it; Tel.: +39-382-986-247
}

Academic Editor: Yongrok Choi

Received: 9 October 2016; Accepted: 26 December 2016; Published: 28 December 2016

\begin{abstract}
We analyze the largely unexplored differences in sustainability reporting within family businesses using a sample of 230 non-financial Italian listed firms for the period 2004-2013. Drawing on legitimacy theory and stakeholder theory, integrated with the socio-emotional wealth (SEW) approach, we study how family control, influence and identification shape a firm's attitude towards disclosing its social and environmental behavior. Our results suggest that family firms are more sensitive to media exposure than their non-family counterparts and that family control enhances sustainability disclosure when it is associated to a family's direct influence on the business, by the founder's presence on the board or by having a family CEO. In cases of indirect influence, without family involvement on the board, the level of family ownership is negatively related to sustainability reporting. On the other hand, a formal identification of the family with the firm by business name does not significantly affect social disclosure.
\end{abstract}

Keywords: sustainability reporting; family firms; legitimacy; stakeholders; socioemotional wealth; Global Reporting Initiative

\section{Introduction}

Society's increased awareness and criticism of the environmental and social impact of corporate activities have coincided with the call for firms to effectively satisfy the need for information emerging from a broader range of constituents than shareholders and creditors [1]. Indeed, firms, since the end of 1990s, have shown a growing attitude to participate in sustainability reporting with the aim to approach in a more comprehensive and systematic way the supply of disclosures encompassing economic, environmental and social issues, in accordance with a construct of corporate sustainability based on social equity, economic and environmental integrity [2].

Empirical literature has widely addressed the issue of corporate voluntary disclosure focusing on individual areas, mostly on the environment. A key assumption behind this stream of literature is that the extent of voluntary disclosure provided by a firm shows the importance it attaches to such matters [3] and a firm would use disclosure in order to communicate its commitment to the environment or to manipulate the perception of its environmental performance [4]. Regarding research interested in the provision, by firms, of information covering multiple areas of social disclosure and, more recently, dealing with sustainability reporting, numerous studies have investigated the relationship between social disclosure and the level of pressure that a company may experience, stemming from the concern and scrutiny of the general population, pressure groups, or significant stakeholders. These studies suggest that firms with a higher visibility-in terms of nature of activity [5], environmental sensitivity of its industry or proximity to consumer [6], media exposure [7,8]—seem to exhibit greater concern to improve their image through voluntary disclosure, and that the different 
groups of stakeholders have different power in influencing social and environmental disclosure [9-11]. Other works have pointed out that corporate governance quality [3] and characteristics, in terms of board composition and attributes [12-14], influence social disclosure practices. Some contributions have tried to explain cross-national differences in corporate social disclosure $[1,15,16]$. Research has also provided some insights into the choice of the reporting media used to communicate social behavior $[17,18]$. Despite the fact that existing literature has dealt with a variety of corporate social and environmental disclosure issues, the reporting practices of family firms, intended as companies where a family is the ultimate controlling owner, are still relatively unexplored [19]. Voluntary disclosure literature focusing on family firms has mainly been concerned with firms' propensity to voluntarily disclose financial information or to provide voluntary disclosures related to corporate governance practices [20-22]. Firms' sustainability reporting is shaped by the relevance attached to different stakeholders, which may be internal such as employees or external such as consumers, society, and environment. In family businesses, things are more complicated because the family itself is an internal stakeholder. Given family businesses' relevance across all world economies [19] it is of interest to understand their sustainability disclosure behavior. Therefore, a great deal of effort is needed in order to point out the differences in this form of reporting within family firms, as they cannot be considered a homogeneous group [23]. Iyer and Lulseged [24] take into account discrete levels of sustainability reporting only for one year, without analyzing the effect of visibility on family businesses' sustainability disclosure over time. Moreover, they address family firms as a homogeneous group without capturing their peculiarities in terms of family influence on management, and they do not find significant differences between family and non-family firms. Campopiano and De Massis [19] explore a wide range of disclosure modes for 98'private and listed family and non-family firms using a cross-sectional analysis. They take into account family-owned firms with at least one family member in management and find differences in behavior between family and non-family firms. What has not yet been investigated is the effect of indirect family influence- - that is, when there are no family members on the board, but the family appoints the members of the board by the means of ownership control [25] — and direct influence by specific forms of owner family involvement. Moreover, Campopiano and De Massis [19] call for large-scale, longitudinal studies with accurate measures of family involvement in order to capture the cause-effect and temporal relationships between sustainability report content and its evolution over time.

Therefore our research questions are:

RQ1: How visibility affects family firms sustainability disclosure behavior in a longitudinal framework? RQ2: How family influence shapes this behavior?

We answer these research questions by analyzing how the level of family ownership, and different forms of family involvement, shape family influence in a firm's disclosure behavior taking into account different forms of visibility for a longitudinal dataset of 230 non-financial Italian listed companies during the period 2004-2013. We address this topic by drawing on legitimacy theory and stakeholder theory, integrated with the socioemotional wealth (SEW) approach. Within the legitimacy theory framework [26], sustainability disclosure is meant as a response to public pressure, in the attempt to prove that firms' behavior is in line with societal norms and values [27]. Legitimacy theory shares these arguments with stakeholder theory [28] —-the latter provides a useful framework to examine social and environmental disclosure as a response to the expectations (or as a means to change perceptions) of particular stakeholder groups [29].

We argue that the relationship between family firms and their stakeholders is strongly influenced by how family businesses pursue and preserve SEW, conceived as the non-financial values that a family derives from its controlling position in the firm [30]. Accordingly, we explore the relationship between the extent of sustainability disclosure and two major dimensions of SEW, namely family control and influence on the business and identification of family members with the firm.

Overall, our study suggests that family control positively affects sustainability disclosure when it is associated to direct influence of the family on the business, by the founder's presence on the board or 
by having a family CEO, but not when associated to indirect influence. When a family exerts indirect influence by mere ownership control, without involvement in the business, the extent of sustainability disclosure is negatively associated with the level of family ownership. Family identification with the firm does not have a significant effect on disclosure when it is formal, that is, the business carries the family name. Our results confirm that a firm's visibility, in terms of media exposure, affects its attitude to disclosure, and this effect is particularly significant for family businesses.

We contribute to prior studies on sustainability disclosure by focusing on family firms and the differences between them. We answer the call from family business literature to better explore the differences within family firms [31,32] by analyzing the extent and type of their social and environmental disclosure. We expand the theoretical framework adopted by many studies in the field of corporate sustainability disclosure, as we use legitimacy theory coupled with stakeholder theory integrated with the SEW approach. We contribute to SEW literature by empirically testing the effect of two main dimensions and pointing out that "family control and influence" is not a homogeneous dimension with a unique effect as it differs depending on whether there is direct or indirect influence and how direct influence is exerted.

The remainder of the paper is organized as follows: Section 2 provides the theoretical background and reviews related literature; Section 3 develops the research hypotheses; Section 4 describes the methodology and data; Sections 5 and 6, respectively, report and discuss the empirical results; and Section 7 concludes, underlines the study's limitations and implications for practice and offers some suggestions for future research.

\section{Theoretical Background and Literature Review}

Literature provides varied interpretations as to why companies become involved in social and environmental responsible activities and in voluntary non-financial disclosure. Legitimacy theory offers a useful theoretical framework in this field as it recognizes that firms operate within a social contract that links the approval of their objectives to a behavior consistent with social values [33]. Legitimacy is defined as "a generalized perception or assumption that the actions of an entity are desirable, proper, or appropriate within some socially-constructed system of norms, values, beliefs and definitions" [34] (p. 574).

Firms try to align their actions to the values of their general and relevant publics and stakeholders [12], as actual or potential inconsistency between social values and the values of the enterprise generates a legitimacy gap [35]. Failure to conform to institutionalized norms of acceptability jeopardizes a firm's organizational legitimacy, resources and durability [36,37].

Firms may use a range of strategies in order to achieve, maintain and repair legitimacy [18,34]. They may inform stakeholders about intended improvements in social performance or shift attention from sensitive issues [38], as well as try to adapt the company's goals, actions and outputs to be consistent with the definition of legitimacy, or change their perceptions through communication $[4,26]$. They often use symbolic actions which "form part of an organization's public image" [14] (p. 481). Communication plays a fundamental role in recognizing a firm's legitimacy as it informs stakeholders, and society, that organizational behavior is congruent with its values, norms and expectations; non-communication may threaten performance, resource availability and survival. Society attaches great importance to companies that engage in reporting their socially-responsible behavior [39]. There is some evidence that companies with a high cost of equity capital tend to initiate sustainability reporting and that initiating firms with superior social responsibility performance attract dedicated institutional investors and analyst coverage, obtaining a reduction in the cost of equity capital [40]. A social reporting commitment is a strategy to change the public perception of a firm's legitimacy [41] and there is increasing evidence of businesses seeking to support their competitive advantage through voluntary disclosure [27].

Stakeholder theory, as well as legitimacy theory, "conceptualize[s] the organization as part of a broader social system wherein the organization impacts, and is impacted by, other groups within society", but while legitimacy theory addresses the expectations of society in general, stakeholder theory recognizes that society is made up of various groups with different views about how 
an organization should behave and with different abilities to influence an organization $[1,7,33]$. Legitimacy and stakeholder theories should be seen as two perspectives of the issue [42] as stakeholder theory offers important insights in order to identify which expectations an organization should meet and what groups of stakeholders might be relevant to its behavior and in fulfilling its objectives. In this perspective, sustainability reporting can be seen as an aspect of the dialog that the company holds with its stakeholders [42], through which it informs them of its good practices [43].

Stakeholders' salience, i.e., the degree to which management prioritizes competing stakeholders demands, is different, and more complex, in a family than in a non-family company as the family itself is a pivotal stakeholder with peculiar claims and concerns [44]. Recent studies underline that the main concern of family firms is not limited to economic performance and argue that their reference point is the preservation of socioemotional wealth [30,45-47]. The concept of socioemotional wealth refers to "the stock of affect-related value that a family derives from its controlling position in a particular firm" [48] (p. 259). SEW draws on several dimensions which make family different from non-family firms and help to explain family businesses' heterogeneity [49,50]. Prior literature identifies five main dimensions: family control and influence on the business, identification of family members with the firm, binding social ties, emotional attachment of family members and renewal of family bonds to the firm through dynastic succession [48]. Family firms show a greater preference for control than non-family businesses in order to preserve family endowment in the business [30,45]. Family members identify more strongly with a family business than non-family owners do with a firm. More favorable firm reputation is associated with having the family name as part of the corporate name, the level of family ownership and a presence on the board [51] as internal and external stakeholders see the firm as an extension of the family [48]. Empirical evidence shows that family firms have more socially-responsible behavior [52,53] as they are particularly concerned with family reputation and image [54]. The sense of identification and belonging is often shared with non-family employees; the ties among the members of this extended family help the development of strong social links with the community and the reciprocal bonds which characterize the family business involve a wide set of constituencies [48]. This social capital is itself a source of wealth for the family that behaves in order to preserve the bonds with its internal and external stakeholders, so family members with deep roots in the community tend to be more sensitive to social and environmental problems [55]. The bonds that family members experience through the business satisfy their needs in terms of belonging and affect, providing them with emotional returns [56], which engender the family's emotional attachment to the firm. The "renewal of family bonds" dimension refers to the family firm principal's purpose to transfer the business to future generations and meet the affective need to perpetuate the family dynasty [57]. For this reason, family owners and managers are concerned with the preservation of the stock of values related to the firm, among them image, reputation and the long-term relationships with internal and external stakeholders [55].

\section{Hypothesis Development}

Organizations try to assure congruence between their value system and the value system shared by the community, and try to display an image that matches with the expectations of their stakeholders. In so doing, they try to attain legitimacy by social and environmental disclosure [58] as providing adequate and verifiable information on their commitment to social and environmental responsible activities consolidates their reputation and stakeholders' trust [59].

Firms which have a greater visibility in terms of size or media exposure are subject to the judgment of a broader community, attract more attention from stakeholders, are more susceptible to political actions which could affect their performance and, hence, are more committed to social disclosure $[3,10,60]$. Social visibility also depends on industry affiliation: firms which operate in businesses with a high potential environmental impact, or companies that are better known to the end consumer, tend to exhibit a higher engagement in social disclosure [6,61]. There is some evidence that companies facing the risk of a tightening of environmental laws engage in sustainability disclosure in order to moderate the extent of public policy pressure $[7,16]$. 
Empirical research [53] shows that family businesses are more committed to the prevention of social concerns, in terms of damage to interest groups, than their non-family counterparts. This suggests that these firms are very concerned with reputation and social legitimation. Family firms care greatly about community scrutiny because it could harm the socioemotional wealth, not only prejudicing their social ties but also damaging the image of the company and, consequently, family reputation, so they try to meet stakeholders' expectations in terms of environment preservation [52]. Therefore, the affective endowment in a firm would be a prosocial stimulus to behave responsibly towards external stakeholders [62]. Family businesses are more prone to adopt initiatives visible to the community such as financing sports teams or sports facilities [63] and charitable giving [64]. More visible firms would be more concerned with social legitimacy and should engage more in social and environmental disclosure [8]. Overall, family firms' literature suggests that family businesses are especially prone to seeking legitimation for their actions, thus enhancing their reputation with stakeholders [65]. We expect that they would more actively respond to visibility pressure by engaging in social reporting in order to influence stakeholder and society perceptions and to be perceived as good corporate citizens [66].

\section{H1: The effect of firm visibility on sustainability disclosure is higher for family than for non-family firms.}

Some studies on social and environmental reporting propose that a firm's internal context affects disclosure [67,68]. Campopiano and De Massis [19] find that family firms are more engaged in social and environmental reporting than their non-family counterparts. All the family firms in their sample have at least one family member in the firm's top management team. This suggests that these findings could be affected by the family involvement in active management; therefore, it is of interest to estimate the effect of different levels of involvement. Several authors suggest that the extent of family involvement shape a firm's attitude towards social and environmental responsible activities and generate heterogeneity among family businesses [69-71]. Bingham et al. [69] assert that increased levels of family involvement bring a collectivistic orientation towards stakeholders as non-economic objectives, such as endorsing the ethical values shared and perpetuated by the family members [71], become more important [30,45]. This transgenerational perspective is enhanced by the presence of the founder in active management [72] who plays a relevant role in the adoption of this collectivistic orientation, enhancing the firm's activism towards the community, employees and the supplying of quality products and services to consumers [69]. According to literature, family businesses, as non-family businesses [73], are more likely to engage in social activities when top management support is high and there is some evidence that the presence of a family CEO enhances social and environmental commitment and communication [70].

The involvement of the family in the business in terms of the presence of multiple family members on the board, family CEO or its founder being still active in the business governance increases the sense of identification between the firm and the family. This implies concern for corporate reputation and the satisfaction of non-family internal stakeholders, resulting in the pursuit of responsible work practices [74]. The presence of multiple family members on the board causes the business to be perceived, by internal and external stakeholders, as an extension of the family and family members would tend to proactively take care of the business' external image [75]. Family firm owner-managers are worried that a firm's bad reputation may damage the "good name" of their family and, in turn, reflect on them as individuals [53] and family firms' founders are more likely to regard their businesses "as an extension of themselves-their identity, or self-view", a mirror of the personal values that they share with the present generations and will transmit to the future ones [49]. A closer identification of the family with the business makes family members more sensitive about the firm's reputation among external stakeholders and they tend to proactively take care of the business' external image [75].

Family firms are characterized by the "embeddedness" of the business within a family [76]. The presence of family members in a firm's management enhances family identification, influence and personal investment in the business, increasing their endowment in the firm and the need to protect it $[49,50]$. Therefore, we expect that firms directly influenced by the family-i.e., with family 
members involved in business management-are more prone to use sustainability disclosure in order to demonstrate that they respect societal values and that they are legitimate to continue their operations.

H2: Family involvement positively affects sustainability disclosure.

Carrying the family name over to the firm strengthens the integration between the family and the firm, inspiring family members to uphold the values of the family firm [77]. Family-owners having their "name on the building" are more conscious of their standing in the firm [78], they may have greater difficulty distancing themselves from the firm they control and, in so doing, would be more concerned with the effect the firm's behavior has on family's reputation [53]. Concern for the environment is more evident in businesses bearing the family name as "soiling the environment reflects badly on family name" [63] (p. 140). In cases where the family and business name is the same, the visibility of the family as controlling coalition of the firm is higher, social monitoring and expectations stronger [74] and, given that public opinion would have heavy emotional effects on family members [79], the family would be more likely to project a positive image of the business through sustainability disclosure.

H3: Family name in business name positively affects sustainability disclosure.

\section{Methodology}

\subsection{Sample}

Our sample comprises publicly-traded firms listed on the Italian Stock Exchange, after checking for the availability of accounting data and excluding financial firms. Some of our explanatory variables are based on accounting data, so, consistently with previous literature, we have excluded financial companies because of the peculiarities of their accounting system [10]. The final sample is represented by an unbalanced panel of 230 firms with data available for the period 2004-2013. We collected the financial, accounting and ownership data from AIDA (Italian Digital Database of Companies), the Italian provider of the Bureau van Dijk European Database. Ownership data was hand-collected cross-checking the information provided by AIDA, the Italian Stock Exchange and CONSOB. Social responsibility disclosure information was hand-collected by the content analysis of stand-alone sustainability reports for each year in the analysis period. The sustainability report is a suitable information recipient also for stakeholders who are less likely to consult the annual report for information but are highly concerned with social issues. The rise in the propensity for firms to publish stand-alone sustainability reports [80] is internationally encouraged and supported by the issue of several sustainability reporting frameworks, among which the Global Reporting Initiative (GRI) Sustainability Reporting Guidelines [81] has become the most adopted standard worldwide.

We define a family firm as one where a family is the ultimate owner, assuming a minimum control threshold of $20 \%$. This definition allows us to highlight the effect of different degrees of family involvement based on ownership, board membership, management, founder and firm-family name identity on voluntary disclosure. The threshold is consistent with those used in the literature [82-85]. Assuming this threshold the family firms in our sample represent the $48.26 \%$ of the Italian non-financial listed companies.

\subsection{Measures}

\subsubsection{Dependent Variables}

We perform a content analysis of stand-alone sustainability reports as they represent one of the more advanced forms of conveying social responsibility disclosures, covering systematically a large spectrum of topics relevant to a wide variety of different stakeholder groups. Most importantly, a sustainability report is a suitable source of information for those individuals and groups less accustomed to reading of the annual report, and perhaps even more interested in social matters than shareholders. Moreover, some studies provide evidence that the adoption of a set of alternative reporting media leads to lower coverage of sustainability issues in the annual report $[17,86]$. 
Iyer and Lulseged [24] analyzing family firms sustainability reporting used a discrete independent variable. They assigned a value of 4,3,2, and 1 when a company issued a sustainability report in 2010, and the report level (self-declared and checked by GRI) was level A, B, C, and below C, respectively; or 0 when a firm did not issue a sustainability report in that year. When a firm did not declare the level, the authors attributed a value in accordance with the GRI G3 guidelines.

In order to avoid the weaknesses of discrete variables, we opted for a continuous index. Based on the GRI Sustainability Reporting Guidelines G3.1 [81], we derived a list of 86 items related to environmental information, labor practices, society respect, product responsibility, human rights, stakeholder engagement, economic performance and market presence. The comparison of sustainability reporting practices with key indicators outlined in the GRI framework is consistent with previous literature on the extent of sustainability disclosure [15,17]. We then performed a content analysis of the sustainability reports in order to assign each firm a numerical rating (ranging from 0 to 1) depending on the number of items actually disclosed. The content analysis we use detects only the presence or absence of the relevant information [6,7,12] given the number of items relative to several different topics it is a good measure of management propensity to provide voluntary social disclosure. For each sample firm, and for each period analyzed, the general disclosure index is calculated as $\mathrm{I}=\Sigma \mathrm{dj} / \mathrm{M}$, where $\mathrm{M}$ is the maximum number of items a firm may disclose, thus excluding the items considered as not-relevant to the specific firm, and dj takes the value 1 if the item $\mathrm{j}$ is disclosed, and 0 if the sustainability report does not present such an item [13]. Further, we compute five sub-indexes, respectively for environment, labor practices, society, human rights respect and product responsibility-related information in order to assess the different emphasis firms place on these themes and, in turn, to understand to which stakeholders they are paying special attention. The related checklists consist of 30 items for environmental information: 15 for labor practices, 10 for human rights respect, 10 for society respect, and 9 for product responsibility.

\subsubsection{Independent Variables}

\section{SEW Related Variables}

Our first proxy for the family control and influence dimension of SEW is family ownership. Moreover, to capture in full the impact of family involvement and influence on sustainability disclosure we use, in the regression models, several other indicators [30,53,64,78,87]: family CEO, presence of multiple family members on the board, presence of the founder in the firm and business bearing the family's name. Family ownership is the sum of equity stakes (\%) that family members have in the firm, directly or indirectly. Family CEO and multiple family members are dummy variables that take value 1 if the CEO is a family member and if multiple family members sit on the board, respectively. The presence of the founder in the firm and the family name are dummy variables that identify the family firms where the founder is involved in the business and where the business carries the family name, respectively.

\section{Control Variables and Interaction Variables}

We include a set of variables that, as found in many previous studies, may correlate with firm disclosure, notably size, profitability and leverage [7,8,10-13,66,88-91]. As a measure of size we use the natural logarithm of sales. Profitability is measured by ROA. Leverage is measured by the gearing ratio, defined as the ratio of long-term and short-term financial debts to equity. We also use Public control [90] defined as a dummy variable that takes value 1 if the firm is owned by public bodies. To control for residual effects related to a specific industry affiliation not captured by the variables "consumer proximity" and "environmental sensitivity", we include in the models sector dummies at the two-digit ATECO level. Consumer proximity $[6,61]$ is measured as a dummy variable that takes value 1 for the firms that are better known to the public (high profile) and 0 otherwise (low profile). Based on prior research, high-profile firms are identified as those in the sectors of household goods and textiles, beverages, food and drug retailers, telecommunications, electricity, gas distribution and 
water. Environmental sensitivity [6,7] is a dummy variable that takes value 1 for firms operating in sectors with a higher risk of environmental impact and 0 otherwise. Based on prior research, the higher environmental risk sectors are mining, oil and gas, chemicals, construction and building materials, forestry and paper, steel and other metals, electricity, gas distribution and water. Media exposure [88] is measured by counting, for each year, the number of articles from the most renowned Italian financial newspaper-“Il Sole 24 Ore"- that contain the firm's name in the sample period 2004-2013. Sport is a dummy to distinguish firms funding sports activities and facilities from the others.

\subsection{Empirical Models}

The presence of multicollinearity is tested based on the correlation matrix and by computing the variance inflation factors. Results indicate that multicollinearity is unlikely to be a problem in our dataset. The statistical analysis includes the use of linear panel regression models to verify the hypotheses reported in the previous section. The panel analysis uses efficiently cross and time-series data, increasing the number of observations and the parameter's reliability while reducing the likelihood of multicollinearity. For the total disclosure index and the four sub-indices, two model formulations are shown that take the following general form:

Model 1: Disclosure scorej $=\mathrm{f}(\mathrm{SEW}$ variables, control variables $)$

Model 2: Disclosure scorej $=\mathrm{f}(\mathrm{SEW}$ variables, family ownership interactions, control variables $)$

\section{Results}

Table 1 reports the descriptive statistics for the dependent and independent variables, distinguishing family and non-family firms. Family firms, as a mean, show a significantly higher propensity to engage in sustainability disclosure than non-family businesses. This attitude is confirmed when focusing on each particular area of sustainability disclosure, namely environment, community, human rights, labor and product. The results of the $t$-tests of differences in the disclosure indexes means are always significant at the conventional level. Our findings show that family firms are significantly more likely to support local sports than their non-family counterparts. Our sample family firms are older, bigger and more profitable than non-family firms. A consistent number of family firms has a family CEO (73.9\%), 51.4\% has the founder on the board and $73 \%$ shows multiple presence of family members on board. On average, families control the company through the absolute majority of ownership stakes. The family lends its name to the company in $25.2 \%$ of the family businesses.

Table 1. Descriptive statistics.

\begin{tabular}{cccccc}
\hline & \multicolumn{2}{c}{ Family Firms } & \multicolumn{2}{c}{ Non-Family Firms } & \multirow{2}{*}{$t$} \\
\cline { 2 - 5 } & Mean & SD & Mean & SD & \\
\hline SUS & 0.056 & 0.188 & 0.024 & 0.117 & $-4.71^{* * *}$ \\
ENV & 0.058 & 0.196 & 0.025 & 0.124 & $-4.74^{* * *}$ \\
SOC & 0.048 & 0.177 & 0.022 & 0.117 & $-3.96^{* * *}$ \\
LAB & 0.066 & 0.220 & 0.033 & 0.154 & $-4.09^{* * *}$ \\
PROD & 0.046 & 0.176 & 0.015 & 0.091 & $-5.12^{* * *}$ \\
HUM & 0.041 & 0.160 & 0.014 & 0.088 & $-4.83^{* * *}$ \\
Size & 12.349 & 1.711 & 11.395 & 2.108 & $-11.03^{* * *}$ \\
Roa & 2.196 & 9.683 & 0.193 & 18.688 & $-4.87^{* * *}$ \\
Gearing ratio & 0.573 & 4.435 & 0.529 & 13.515 & 1.39 \\
Media Exposure & 12.707 & 39.069 & 9.035 & 29.466 & 1.50 \\
Consumer Prox & 0.351 & 0.478 & 0.230 & 0.421 & $-6.45^{* * *}$ \\
Environmental Sens & 0.541 & 0.499 & 0.340 & 0.474 & $-9.42^{* * *}$ \\
Sport & 0.270 & 0.444 & 0.200 & 0.400 & $-4.05^{* * *}$ \\
qFamily & 58.971 & 14.764 & - & - & - \\
FamilyCEO & 0.739 & - & - & - & - \\
Founder & 0.514 & - & - & - & - \\
FMulty & 0.730 & - & - & - & - \\
FamilyName & 0.252 & - & - & - & \\
\hline & Note: $* * *$ & $p$-value significant at the $1 \%$ level. &
\end{tabular}

Table 2 presents the results of the correlation analysis. Overall, these results suggest that multicollinearity will not be a major concern in the following regression analysis. 
Table 2. Correlation analysis.

\begin{tabular}{|c|c|c|c|c|c|c|c|c|c|c|c|c|c|c|c|c|c|c|}
\hline & 0 & 1 & 2 & 3 & 4 & 5 & 6 & 7 & 8 & 9 & 10 & 11 & 12 & 13 & 14 & 15 & 16 & 17 \\
\hline \multicolumn{19}{|l|}{0 SUS } \\
\hline $1 \mathrm{ENV}$ & 0.986 & & & & & & & & & & & & & & & & & \\
\hline $2 \mathrm{SOC}$ & 0.975 & 0.949 & & & & & & & & & & & & & & & & \\
\hline $3 \mathrm{LAB}$ & 0.977 & 0.958 & 0.938 & & & & & & & & & & & & & & & \\
\hline 4 PROD & 0.938 & 0.911 & 0.930 & 0.893 & & & & & & & & & & & & & & \\
\hline $5 \mathrm{HUM}$ & 0.913 & 0.875 & 0.894 & 0.859 & 0.859 & & & & & & & & & & & & & \\
\hline 6 Size & 0.466 & 0.459 & 0.454 & 0.455 & 0.438 & 0.425 & & & & & & & & & & & & \\
\hline 7 Roa & 0.020 & 0.024 & 0.018 & 0.017 & 0.005 & 0.020 & 0.058 & & & & & & & & & & & \\
\hline 8 Gearing ratio & -0.027 & -0.028 & -0.025 & -0.028 & -0.024 & -0.022 & -0.022 & -0.006 & & & & & & & & & & \\
\hline 9 Public & 0.430 & 0.422 & 0.420 & 0.420 & 0.416 & 0.385 & 0.378 & 0.014 & -0.026 & & & & & & & & & \\
\hline 10 DConsumer Prox & 0.049 & 0.042 & 0.052 & 0.039 & 0.070 & 0.062 & 0.056 & 0.024 & -0.022 & 0.168 & & & & & & & & \\
\hline 11 DEnvironmental Sens & 0.165 & 0.169 & 0.159 & 0.151 & 0.128 & 0.182 & 0.182 & 0.001 & 0.021 & 0.192 & -0.230 & & & & & & & \\
\hline 12 Media Exposure & 0.442 & 0.424 & 0.425 & 0.420 & 0.441 & 0.476 & 0.457 & 0.015 & -0.014 & 0.254 & 0.070 & 0.105 & & & & & & \\
\hline 13 DSport & 0.182 & 0.193 & 0.157 & 0.166 & 0.152 & 0.175 & 0.205 & 0.025 & -0.025 & 0.116 & 0.056 & 0.116 & 0.156 & & & & & \\
\hline 14 DFounder & -0.058 & -0.048 & -0.075 & -0.062 & -0.063 & -0.054 & -0.012 & 0.079 & -0.019 & -0.183 & -0.070 & -0.090 & -0.125 & -0.053 & & & & \\
\hline 15 qFamily & -0.079 & -0.075 & -0.086 & -0.081 & -0.071 & -0.070 & 0.058 & 0.105 & -0.020 & -0.253 & 0.084 & 0.113 & -0.071 & 0.094 & 0.547 & & & \\
\hline 16 DFamilyCEO & -0.030 & -0.024 & -0.042 & -0.027 & -0.035 & -0.038 & 0.089 & 0.113 & -0.017 & -0.192 & 0.058 & 0.100 & -0.090 & 0.049 & 0.488 & 0.736 & & \\
\hline 17 DFMulty & -0.001 & 0.004 & -0.018 & -0.011 & 0.004 & 0.010 & 0.119 & 0.077 & -0.012 & -0.189 & 0.084 & 0.109 & 0.016 & 0.054 & 0.495 & 0.726 & 0.629 & \\
\hline 18 DFamilyName & -0.047 & -0.047 & -0.037 & -0.057 & -0.041 & -0.035 & 0.050 & 0.048 & 0.008 & -0.112 & 0.032 & 0.076 & -0.033 & -0.002 & 0.148 & 0.401 & 0.306 & 0.366 \\
\hline
\end{tabular}

Note: correlations in bold are significant at the $5 \%$ level. 
Table 3 shows the results of the Ordinary Least Squares (OLS) regression analysis performed through a basic model (model 1) and a model with interactions (model 2) using the sustainability index as dependent variable.

Table 3. General disclosure index-Panel OLS regressions.

\begin{tabular}{|c|c|c|}
\hline Variables & Model 1 & Model 2 \\
\hline Interc. & $-0.238^{* * *}$ & $-0.240 * * *$ \\
\hline \multicolumn{3}{|l|}{ Controls Variables } \\
\hline Size & $0.021 * * *$ & $0.020 * * *$ \\
\hline Roa & -0.000 & -0.000 \\
\hline Gearing ratio & -0.000 & -0.000 \\
\hline Public & $0.207^{* * *}$ & $0.211^{* * *}$ \\
\hline Consumer Proximity & $0.050 * *$ & $0.052 * *$ \\
\hline Environmental Sensitivity & -0.002 & 0.005 \\
\hline Media Exposure & $0.002 * * *$ & $0.001 * * *$ \\
\hline Sport & $0.033^{* * *}$ & $0.054 * * *$ \\
\hline Industry & Yes & Yes \\
\hline \multicolumn{3}{|l|}{ SEW Variables } \\
\hline qFamily & $-0.001 * * *$ & -0.000 \\
\hline FamilyCEO & $0.027^{* *}$ & $0.025 * *$ \\
\hline Founder & $0.024^{* *}$ & $0.031^{* * *}$ \\
\hline FMulty & 0.013 & 0.007 \\
\hline FamilyName & -0.013 & -0.013 \\
\hline \multicolumn{3}{|l|}{ Interactions Variables } \\
\hline qFamily $\times$ Media Exposure & & $0.000 * * *$ \\
\hline qFamily $\times$ Sport & & $-0.001 * *$ \\
\hline qFamily $\times$ Consumer Proximity & & -0.000 \\
\hline qFamily $\times$ Environmental Sensitivity & & $-0.001^{* *}$ \\
\hline $\mathrm{R}^{2}$ & 0.382 & 0.386 \\
\hline
\end{tabular}

Note: ${ }^{*}, * *, * * * p$-value significant at the $10 \%, 5 \%$ and $1 \%$ level.

The $\mathrm{F}$ test for both models is significant at the $1 \%$ level. Model 1 presents an adjusted $\mathrm{R}^{2}$ of 0.382 , the explicative power of the model rises to 0.386 adding the interaction variables. Both models highlight that general sustainability disclosure score is significantly and positively affected by firm size, consistent with prior research in the UK [12,24,92]. Our findings confirm the positive and significant effect of media exposure highlighted in literature $[6,88]$. We find a significant positive relation between the proximity of the business to the consumer and the sustainability score, coherent with the results of Branco and Rodrigues [4] for Portuguese companies, although for these firms the effect was not significant. Consistent with this study, environmental sensitivity is positively related to disclosure but never significant. In line with empirical literature $[6,88]$, we find that profitability does not influence the attitude to disclose a firm's social behavior. We confirm that a firm's capital structure does not affect sustainability disclosure as we find, consistent with the literature [12,93] a negative but not significant relation with the gearing ratio. Our results show that firms that engage in sports funding are significantly more sensitive to corporate sustainability disclosure and this is coherent with the suggestions of Smith and Westerbeek [94] on the role that sport can play as a vehicle for deploying a social responsible behavior. Like Cheng and Courtenay [89], who find that governmental ownership has a positive- but not significant-relation with disclosure, we find a strong and significant positive effect of public control on the business.

As regards the variables that characterize specifically family businesses, in model 1 we find that family ownership has a significant negative effect on sustainability although family business are more engaged in sustainability disclosure than non-family businesses. According to $\mathrm{H} 2$, family $\mathrm{CEO}$ and the presence of the founder on the board have, in both models, a positive and significant effect. Unlike the 
evidence of Ho and Wong [93] on financial voluntary disclosure, we find that the presence of multiple family members on the board has a positive, but not significant, effect on sustainability reporting. Unlike the predictions hypothesized in $\mathrm{H} 3$, family name does not affect sustainability disclosure.

When we add the interactions [95] in model 2, the signs and significance of the control variables, and of the SEW variables, do not change, except for family ownership. The interaction between family ownership and media exposure is significantly positive, that is to say that visibility reinforces family firms' disclosure propensity and that family-controlled firms are more sensitive to media exposure than non-family businesses. The interactions of family ownership with consumer proximity do not show any differential effect in family-controlled businesses. The interaction between family ownership and environmental sensitivity shows that the positive effect of the latter on disclosure is mitigated by family control. These results suggest that $\mathrm{H} 1$ is confirmed when a family firm's visibility is related to media exposure.

The interaction between family ownership and sports funding is negative, that is the relation between the propensity to engage in sustainability reporting, and sport supporting, is lower for family than for non-family firms.

Table 4 reports the results of the pooling regressions for the specific indexes related to environment, society, human rights, labor and product responsibility disclosure.

Overall, the control variables maintain the sign and significance pointed out using the sustainability index, except for the presence of a family CEO, which is not significant for product responsibility, human rights and society. The regression results show that the presence of multiple family members on the board has a positive, but never significant, effect for the specific disclosure indexes, as it does for the general sustainability index. The interaction variables maintain the same sign and significance shown in the case of the general sustainability index, with the exception of the interaction between family ownership and environmental sensitivity; this loses significance for product responsibility and human rights respect disclosure.

The explicative power of model 2, using the specific disclosure indexes, ranges from 0.356 to 0.373 .

Table 4. Disclosure sub-indexes-Panel OLS regressions.

\begin{tabular}{|c|c|c|c|c|c|}
\hline \multicolumn{6}{|c|}{ PANEL A-Model 1} \\
\hline Variables & Environment & Society & Labour & Prod. Responsibility & Hum. Rights \\
\hline Interc. & $-0.249^{* * *}$ & $-0.242^{* * *}$ & $-0.277^{* * *}$ & $-0.199^{* * *}$ & $-0.151^{* * *}$ \\
\hline \multicolumn{6}{|l|}{ Controls } \\
\hline Size & $0.021 * * *$ & $0.021 * * *$ & $0.024^{* * *}$ & $0.017^{* * *}$ & $0.013^{* * *}$ \\
\hline Roa & -0.000 & -0.000 & -0.000 & -0.000 & -0.000 \\
\hline Gearing ratio & -0.000 & -0.000 & -0.000 & -0.000 & -0.000 \\
\hline Public & $0.210^{* * *}$ & $0.190^{* * *}$ & $0.237 * * *$ & $0.195^{* * *}$ & $0.148^{* * *}$ \\
\hline Cons Proximity & $0.054^{* *}$ & $0.055^{* * *}$ & $0.058^{* *}$ & $0.055^{* * *}$ & 0.022 \\
\hline Env. Sensitivity & 0.001 & -0.004 & -0.001 & -0.006 & -0.004 \\
\hline Media Exposure & $0.002^{* * *}$ & $0.001 * * *$ & $0.002 * * *$ & $0.002^{* * *}$ & $0.002^{* * *}$ \\
\hline Sport & $0.042^{* * *}$ & $0.021 * *$ & $0.029 * * *$ & $0.023^{* *}$ & $0.025^{* * *}$ \\
\hline Industry & Yes & Yes & Yes & Yes & Yes \\
\hline \multicolumn{6}{|l|}{ SEW Variables } \\
\hline qFamily & $-0.001^{* * *}$ & $-0.001^{* * *}$ & $-0.001^{* * *}$ & $-0.000 * *$ & $-0.001^{* * *}$ \\
\hline FamilyCEO & $0.029^{* *}$ & 0.020 & $0.036^{* *}$ & 0.015 & 0.013 \\
\hline Founder & $0.030^{* * *}$ & 0.016 & $0.025 *$ & 0.016 & $0.018 *$ \\
\hline FMulty & 0.017 & 0.004 & 0.007 & 0.013 & 0.013 \\
\hline FamilyName & -0.017 & -0.003 & -0.024 & -0.011 & -0.005 \\
\hline $\mathrm{R}^{2}$ & 0.370 & 0.355 & 0.357 & 0.352 & 0.356 \\
\hline
\end{tabular}


Table 4. Cont.

\begin{tabular}{|c|c|c|c|c|c|}
\hline \multicolumn{6}{|c|}{ PANEL B-Model 2} \\
\hline Variables & Environment & Society & Labour & Prod. Responsibility & Hum. Rights \\
\hline Interc. & $-0.252^{* * *}$ & $-0.244^{* * *}$ & $-0.277^{* * *}$ & $-0.201^{* * *}$ & $-0.151^{* * *}$ \\
\hline \multicolumn{6}{|l|}{ Controls } \\
\hline Size & $0.021^{* * *}$ & $0.021 * * *$ & $0.024^{* * *}$ & $0.017^{* * *}$ & $0.012 * * *$ \\
\hline Roa & -0.000 & -0.000 & -0.000 & -0.000 & -0.000 \\
\hline Gearing ratio & -0.000 & -0.000 & -0.000 & -0.000 & -0.000 \\
\hline Public & $0.208^{* * *}$ & $0.190 * * *$ & $0.243^{* * *}$ & $0.202 * * *$ & $0.150 * * *$ \\
\hline Cons Proximity & $0.056^{* *}$ & $0.055^{* *}$ & $0.055^{* *}$ & $0.070 * * *$ & 0.026 \\
\hline Env. Sensitivity & 0.007 & 0.004 & 0.011 & -0.004 & 0.001 \\
\hline Media Exposure & $0.001 * * *$ & $0.001 * * *$ & $0.001 * * *$ & $0.001 * * *$ & $0.001 * * *$ \\
\hline Sport & $0.068 * * *$ & $0.045^{* * *}$ & $0.051^{* * *}$ & $0.043^{* * *}$ & $0.037^{* * *}$ \\
\hline Industry & Yes & Yes & Yes & Yes & Yes \\
\hline \multicolumn{6}{|l|}{ SEW Variables } \\
\hline qFamily & -0.000 & 0.000 & -0.000 & -0.000 & -0.000 \\
\hline FamilyCEO & $0.027^{* *}$ & 0.018 & $0.034^{* *}$ & 0.013 & 0.012 \\
\hline Founder & $0.035 * * *$ & $0.022 * *$ & $0.035^{* * *}$ & $0.023 * *$ & $0.022 * *$ \\
\hline FMulty & 0.013 & -0.001 & 0.001 & 0.005 & 0.010 \\
\hline FamilyName & -0.017 & -0.002 & -0.023 & -0.012 & -0.005 \\
\hline \multicolumn{6}{|l|}{ SEW Interactions } \\
\hline qFamily $\times$ Media Exp. & $0.000 *$ & $0.000^{* * *}$ & $0.000 * * *$ & $0.000 * * *$ & $0.000^{* *}$ \\
\hline qFamily $\times$ Sport & $-0.001 * *$ & $-0.001 * *$ & $-0.001 *$ & $-0.001 * *$ & -0.000 \\
\hline qFamily $\times$ Cons. Prox. & -0.000 & -0.000 & -0.000 & -0.000 & -0.000 \\
\hline qFamily $\times$ Env. Sensitivity & $-0.001 *$ & $-0.001 * *$ & $-0.001^{* * *}$ & -0.000 & -0.000 \\
\hline$R^{2}$ & 0.373 & 0.359 & 0.364 & 0.356 & 0.358 \\
\hline
\end{tabular}

Note: ${ }^{* * *}, * * * p$-value significant at the $10 \%, 5 \%$ and $1 \%$ level.

\section{Discussion}

Firms seek legitimacy by converging values pursued by the company, with the values shared by society, and making this convergence evident in the eyes of society $[12,34,35]$. Society is not a homogeneous group of individuals with identical expectations and a firm's different groups of stakeholders are members of society [96]. Businesses seek legitimacy by different stakeholder groups depending on how they help to achieve the firm's goals. Family businesses' behavior is strongly influenced by non-economic objectives, i.e., family members' socioemotional wealth preservation [30,45]. Sustainability disclosure is a means of demonstrating to stakeholders that a firm's actions are in accordance with the system of values shared by society and thus preserve the SEW. The business is seen as an extension of the family itself because of a strong sense of identification between family members and the firm. Through the business, a family binds important social ties-with vendors, suppliers, employees and the community - which give family members a relevant emotional and reputational return. Within the firm family members can satisfy their needs for affection and belonging which may also involve non-family employees as members of the extended family [48]. A family business is strongly legitimated to exist for an extended period as it allows the objectives of the internal stakeholders, both monetary and non-monetary, to be achieved. It will renew the family bond and provide socioemotional wealth to the future generations through dynastic succession. In general, family businesses are concerned with both internal and external stakeholders and they are more prone to disclose their corporate social responsible behavior.

Our findings confirm that visibility increases a firm's voluntary disclosure and demonstrate that media exposure significantly affects family businesses sustainability reporting. This is likely to be due to the dual effect of the media: the media exposes the family to the scrutiny of "wider society", of groups with which the company has no social bonds, and it can also influence community perceptions of a business [97]. The image of the family is the mirror image of the company so firms are particularly concerned with this type of visibility and, as a result, are more prone to disclose their social behavior, as suggested by H1. Our results show that the positive relation between sports funding and disclosure, which emerged for all firms, changes sign in the case of family firms; it could be explained 
as a substitution effect between funding sport and voluntary disclosure because the former is a means of building a stronger corporate image in the community where a firm operates.

As mentioned above, socioemotional wealth comprises different dimensions and, on the basis of our results, "family control and influence" and "identification" do not seem to have the same effect on sustainability disclosure. Moreover, "family control and influence" is not a homogeneous dimension because its effect depends on how a family exerts its influence on the firm. An owning family may exert its control on the business indirectly, by appointing the CEO and the board, or directly by having a family CEO and by having a presence on the board. Our study suggests that indirect control, i.e., family ownership without the presence of the family in management, does not affect disclosure and that what really matters is the family's direct influence by its involvement in the business. Our study shows that when family ownership increases, in absence of family involvement, we have a negative effect on disclosure. In this case, the relevance of external shareholders decreases, the absence of the family in management limits the affective endowments in the firm so concern for external stakeholders falls as the family prefers to devote resources to satisfying the groups that would reinforce family control [55].

Thus, our empirical finding shed lights on the effect of a second important dimension of SEW, namely family members' identification with the firm. The sense of identification depends on the family's proximity to the business. We may have a considerable proximity when the family is actively involved in business governance and management and a formal proximity when the firm bears the family name. Our results confirm $\mathrm{H} 2$ and suggest that the sense of identification is stronger, and the attitude to preserve/enhance family image and reputation through disclosure higher, when the family is considerably close to the business. Family involvement through the CEO, or by having the founder on the board, has a significant positive effect on disclosure while the multiple presence of board members does not affect sustainability disclosure. Multiple family members on the board may belong to different branches of the family, rather than the founder's nuclear family, and they may even be in conflict with each other. In this case, the SEW and the sense of identification tend to lessen. The founder's presence and a family CEO strongly affect environmental and labor respect disclosure. Previous research points out that family firms behave consistently with respect for the environment [52] and for their employees, by improving their quality of life [98] and more stable employment [99]; our results go further by suggesting that family firms choose to actively engage in formal communication-i.e., sustainability reporting - to show their interest in these stakeholders.

Our findings do not support $\mathrm{H} 3$ and suggest that if a family is formally, by the means of name, but not considerably close to the business we do not have an effect on sustainability disclosure.

\section{Conclusions}

This paper focuses on a sample of 230 Italian non-financial listed firms. It studies sustainability disclosure, by the means of a continuous index determined for each year of the period 2004-2013. It highlights that the way family ownership affects sustainability reporting depends on how the family exerts its influence on the business. The presence of the founder on the board or a family CEO have a significant positive effect, in particular on environment and labor disclosure, because of the family's closer identification with the business through its active involvement in the firm. Moreover, it shows that a formal identification of the family and the firm by the means of the name of the business does not affect disclosure. Our study confirms the relevant effect on disclosure of some industry and firm characteristics suggested by prior studies, such as consumer proximity, firm size and media exposure. We extend prior research by pointing out a higher effect of media pressure for family firms and the positive relation between a firm's propensity to finance sport and sustainability reporting. However, this is lower for family firms. Further, our empirical evidence points out that family firms operating in environmentally-sensitive industries are less prone to disclose their behavior toward sustainability than non-family businesses. 
This study has some practical implications. It provides valuable information for public policy makers which may address more effectively their regulatory activity taking into account the different motivations which affect family firms' attitude towards sustainability disclosure in different aspects, namely environment, society, human rights, labor and product responsibility. The information on the motivations and incentives underlying the decision to disclose on the various aspects of corporate sustainability has implications also for investors, employees and consumers, as it can help them in selecting which companies to invest their money in, their work or in choosing whose products to buy. It has practical implications for family firms, especially those operating in environmentally-sensitive industries, suggesting better management of voluntary disclosure as it has a strategic function as well as a communicative one to those outside the company. Our findings indicate, for the family-owned firms, a possible need for improvement in the areas of the impact on product responsibility, providing accounting practitioners with useful information in order to assist effectively these businesses in the sustainability-reporting process.

This study presents some limitations. As a proxy for SEW, we use the percentage of shares controlled by a family as it is the only valuable alternative for research based on large archival databases [48]. This variable measures the "family control and influence" dimension but is not able to capture other aspects such as family members' sense of identification with the business and willingness to transfer the business to future generations, relations within the owning family and between the family and other stakeholders. Further studies could overcome these limitations by using different research methods such as surveys and case studies, in order to develop a multidimensional measurement of family-affective endowment in the firm and evaluate the impact of all SEW dimensions on sustainability disclosure.

Another limit of this study, which could be addressed by further research, is that it takes into account only three moderators of family endowment, namely family CEO, founder and multiple family members on the board. However, other factors affect endowment, modifying the relationship with stakeholders and the need to gain legitimacy, such as a qualified presence of non-family shareholders, the family's generational stage, family conflicts and litigation. Moreover, this study is single-country focused and it would be useful to address its topics on an international sample in order to evaluate the effect of different institutional settings and environmental issues on family and non-family firms' sustainability disclosure.

Acknowledgments: The authors are grateful to the Editor and to the anonymous reviewers for their valuable comments.

Author Contributions: Giovanna Gavana, Pietro Gottardo and Anna Maria Moisello conceived and designed the study; Giovanna Gavana, Pietro Gottardo and Anna Maria Moisello constructed the database and analyzed the data; Giovanna Gavana, Pietro Gottardo and Anna Maria Moisello contributed analyses tools; Giovanna Gavana, Pietro Gottardo and Anna Maria Moisello wrote the paper.

Conflicts of Interest: The authors declare no conflict of interest.

\section{References}

1. Van der Laan Smith, J.; Adhikari, A.; Tondkar, R.H. Exploring differences in social disclosures internationally: A stakeholder perspective. J. Account. Public Policy 2005, 24, 123-151. [CrossRef]

2. Bansal, P. Evolving sustainably: A longitudinal study of corporate sustainable development. Strat. Manag. J. 2005, 26, 197-218. [CrossRef]

3. Chan, M.C.; Watson, J.; Woodliff, D. Corporate governance quality and CSR disclosures. Bus. Ethics 2014, 125, 59-73. [CrossRef]

4. $\quad$ Ling, Q.; Mowen, M.M. Competitive strategy and voluntary environmental disclosure: Evidence from the chemical industry. J. Account. Public Policy 2013, 13, 55-84. [CrossRef]

5. Brammer, S.; Pavelin, S. Voluntary social disclosures by large UK Companies. Bus. Ethics 2004, 13, 86-99. [CrossRef]

6. Branco, M.C.; Rodrigues, L.L. Factors influencing social responsibility disclosure by Portuguese companies. Bus. Ethics 2008, 83, 685-701. [CrossRef] 
7. Fernandez-Feijoo, B.; Romero, S.; Ruiz, S. Effect of Stakeholders' Pressure on Transparency of Sustainability Reports within the GRI Framework. Bus. Ethics 2014, 122, 53-63. [CrossRef]

8. Gamerschlag, R.; Möller, K.; Verbeeten, F. Determinants of voluntary CSR disclosure: Empirical evidence from Germany. Rev. Manag. Sci. 2011, 5, 233-262. [CrossRef]

9. Patten, D.M. Media Exposure, Public Policy Pressure, and Environmental Disclosure: An Examination of the Impact of Tri Data Availability. Account. For. 2002, 26, 152-171. [CrossRef]

10. Reverte, C. Determinants of corporate social responsibility disclosure ratings by Spanish listed firms. Bus. Ethics 2009, 88, 351-366. [CrossRef]

11. Roberts, R.W. Determinants of corporate social responsibility disclosure: An application of stakeholder theory. Account. Organ. Soc. 1992, 17, 595-612. [CrossRef]

12. Haniffa, R.M.; Cooke, T.E. The impact of culture and governance on corporate social reporting. J. Account. Public Policy 2005, 24, 391-430. [CrossRef]

13. Khan, A.; Muttakin, M.B.; Siddiqui, J. Corporate governance and corporate social responsibility disclosures: Evidence from an emerging economy. Bus. Ethics 2013, 114, 207-223. [CrossRef]

14. Michelon, G.; Parbonetti, A. The effect of corporate governance on sustainability disclosure. J. Manag. Gov. 2012, 16, 477-509. [CrossRef]

15. Fifka, M.S.; Drabble, M. Focus on Standardization of Sustainability Reporting-A Comparative Study of the United Kingdom and Finland. Bus. Strategy Environ. 2012, 21, 455-474. [CrossRef]

16. Guthrie, J.; Parker, L.D. Corporate social disclosure practice: A comparative international analysis. Adv. Public Interest Account. 1990, 3, 159-175.

17. Frost, G.; Jones, S.; Loftus, J.; van der Laan, S. A survey of sustainability reporting practice of Australian reporting entities. Austral. Account. Rev. 2005, 15, 89-96. [CrossRef]

18. Holder-Webb, L.; Cohen, J.R.; Nath, L.; Wood, D. The supply of Corporate Social Responsibility Disclosures among U.S. Firms. Bus. Ethics 2009, 84, 497-527. [CrossRef]

19. Campopiano, G.; de Massis, A. Corporate social responsibility reporting: A content analysis in family and non-family firms. Bus. Ethics 2015, 129, 511-534. [CrossRef]

20. Ali, A.; Chen, T.Y.; Radhakrishnan, S. Corporate disclosures by family firms. J. Account. Econ. 2007, 44, 238-286. [CrossRef]

21. Chen, S.; Chen, X.; Cheng, Q. Do family firms provide more or less voluntary disclosure? J. Account. Res. 2008, 46, 499-536. [CrossRef]

22. Hutton, A.P. A discussion of 'corporate disclosure by family firms'. J. Account. Econ. 2007, 44, 287-297. [CrossRef]

23. Chua, J.H.; Chrisman, J.J.; Steier, L.P.; Rau, S.B. Sources of heterogeneity in family firms: An introduction. Entrepreneurship 2012, 36, 1103-1113. [CrossRef]

24. Iyer, V.; Lulseged, A. Does family status impact US firms' sustainability reporting? Sustain. Acc. Manag. Pol. J. 2013, 4, 163-189. [CrossRef]

25. Dowling, J.; Pfeffer, J. Organizational legitimacy: Social values and organizational behavior. Pac. Sociol. Rev. 1975, 18, 122-136. [CrossRef]

26. Hooghiemstra, R. Corporate communication and impression management: New perspective why companies engage in Corporate Social Reporting. Bus. Ethics 2000, 27, 55-68. [CrossRef]

27. Astrachan, J.H.; Klein, S.B.; Smyrnios, K.X. The F-PEC scale of family influence: A proposal for solving the family business definition problem. Fam. Bus. Rev. 2002, 15, 45-58. [CrossRef]

28. Freeman, R.E. Strategic management. In A Stakeholder Approach; Pitman: Boston, MA, USA, 1984.

29. Deegan, C.; Blomquist, C. Stakeholder influence on corporate reporting: An exploration of the interaction between WWF-Australia and the Australian minerals industry. Account. Org. Soc. 2006, 31, 343-372. [CrossRef]

30. Gomez-Mejia, L.R.; Haynes, K.T.; Nunez-Nickel, M.; Jacobson, K.J.L.; Moyano-Fuentes, J. Socioemotional wealth and business risks in family-controlled firms: Evidence from Spanish olive oil mills. Adm. Sc. Q. 2007, 52, 106-137.

31. Salvato, C.; Moores, K. Research on accounting in family firms: Past accomplishments and future challenges. Fam. Bus. Rev. 2010, 23, 193-215. [CrossRef]

32. Uhlaner, L.M.; Kellermanns, F.; Eddeleston, K.; Hoy, F. The entrepreneuring family: A new paradigm for family business research. Small Bus. Econ. 2012, 38, 1-11. [CrossRef]

33. Deegan, C. Introduction: The legitimizing effect of social and environmental disclosures-a theoretical foundation. Account. Aud. Account. J. 2002, 15, 282-311. [CrossRef] 
34. Suchman, M.C. Managing legitimacy: Strategic and institutional approaches. Acad. Manag. J. 1995, 20, 571-610.

35. Sethi, S.P. A conceptual framework for environmental analysis of social issues and evaluation of business response patterns. Acad. Manag. J. 1979, 4, 63-74.

36. Oliver, C. Strategic responses to institutional processes. Acad. Manag. J. 1991, 16, 145-179. [CrossRef]

37. Scott, W.R. The adolescence of institutional theory. Adm. Sci. Q. 1987, 493-511. [CrossRef]

38. Lindblom, C.K. The implications of organizational legitimacy for corporate social performance and disclosure. In Proceedings of the Critical Perspectives on Accounting Conference, New York, NY, USA, 20 April 1994.

39. Fisher, J.; Gunz, S.; McCutcheon, J. Private/public interest and the enforcement of a code of professional conduct. Bus. Ethics 2001, 31, 191-207. [CrossRef]

40. Dhaliwal, D.S.; Li, O.Z.; Tsang, A.; Yang, Y.G. Voluntary nonfinancial disclosure and the cost of equity capital: The initiation of corporate social responsibility reporting. Acc. Rev. 2011, 86, 59-100. [CrossRef]

41. Deegan, C.; Rankin, M.; Voght, P. Firms' disclosure reactions to major social incidents: Australian evidence. Account. For. 2000, 24, 101-130. [CrossRef]

42. Gray, R.; Kouhy, R.; Lavers, S. Corporate social and environmental reporting: A review of the literature and a longitudinal study of UK disclosure. Account. Aud. Account. J. 1995, 8, 47-77. [CrossRef]

43. Clatworthy, M.; Jones, M.J. The effect of thematic structure on the variability of annual report readability. Account. Aud. Account. J. 2001, 14, 311-326. [CrossRef]

44. Mitchell, R.K.; Agle, B.R.; Chrisman, J.J.; Spence, L.J. Toward a theory of stakeholder salience in family firms. Bus. Ethics Q. 2011, 21, 235-255. [CrossRef]

45. Kalm, M.; Gomez-Mejia, L.R. Socioemotional wealth preservation in family firms. Rev. Adm. 2016, 51, 409-411. [CrossRef]

46. Cruz, C.; Justo, R.; de Castro, J.O. Does family employment enhance MSEs performance?: Integrating socioemotional wealth and family embeddedness perspectives. J. Bus. Vent. 2012, 27, 62-76. [CrossRef]

47. Leitterstorf, M.P.; Rau, S.B. Socioemotional wealth and IPO underpricing of family firms. Strateg. Manag. J. 2014, 35, 751-760. [CrossRef]

48. Berrone, P.; Cruz, C.; Gomez-Mejia, L.R. Socioemotional wealth in family firms theoretical dimensions, assessment approaches, and agenda for future research. Fam. Bus. Rev. 2012, 25, 258-279. [CrossRef]

49. Gomez-Mejia, L.R.; Cruz, C.; Berrone, P.; de Castro, J. The bind that ties: Socioemotional wealth preservation in family firms. Acad. Manag. Ann. 2011, 5, 653-707. [CrossRef]

50. Vandekerkhof, P.; Steijvers, T.; Hendriks, W.; Voordeckers, W. The effect of organizational characteristics on the appointment of nonfamily managers in private family firms: The moderating role of socioemotional wealth. Fam. Bus. Rev. 2015, 28, 104-122. [CrossRef]

51. Deephouse, D.L.; Jaskiewicz, P. Do Family Firms Have Better Reputations than Non-Family Firms? An Integration of Socioemotional Wealth and Social Identity Theories. J. Manag. Stud. 2013, 50, 337-360. [CrossRef]

52. Berrone, P.; Cruz, C.; Gomez-Mejia, L.R.; Larraza-Kintana, M. Socioemotional wealth and corporate responses to institutional pressures: Do family-controlled firms pollute less? Adm. Sci. Q. 2010, 55, 82-113. [CrossRef]

53. Dyer, W.G.; Whetten, D.A. Family firms and social responsibility: Preliminary evidence from the S\&P 500. Entrep. Theory Parct. 2006, 30, 785-802.

54. Sharma, P.; Manikutty, S. Strategic divestments in family firms: Role of family structure and community culture. Entrep. Theory Parct. 2005, 29, 293-311. [CrossRef]

55. Cennamo, C.; Berrone, P.; Cruz, C.; Gomez-Mejia, L.R. Socioemotional Wealth and Proactive Stakeholder Engagement: Why Family-Controlled Firms Care More about Their Stakeholders. Entrep. Theory Parct. 2012, 36, 1153-1173. [CrossRef]

56. Astrachan, J.H.; Jaskiewicz, P. Emotional returns and emotional costs in privately held family businesses: Advancing traditional business valuation. Fam. Bus. Rev. 2008, 21, 139-149. [CrossRef]

57. Zellweger, T.M.; Kellermanns, F.W.; Chrisman, J.J.; Chua, J.H. Family control and family firm valuation by family CEOs: The importance of intentions for transgenerational control. Org. Sci. 2012, 23, 851-868. [CrossRef]

58. Deegan, C. Organisational legitimacy as a motive for sustainability reporting. In Sustainability Accounting and Accountability; Unerman, J., Bebbington, J., O’Dwyer, B., Eds.; Routledge: London, UK, 2007; pp. 127-149. 
59. Perrini, F. Building a European portrait of corporate social responsibility reporting. Europ. Manag. J. 2005, 23, 611-627. [CrossRef]

60. Morhardt, J.E. Corporate social responsibility and sustainability reporting on the internet. Bus Strategy Environ. 2010, 19, 436-452. [CrossRef]

61. Clarke, J.; Gibson-Sweet, M. The use of corporate social disclosures in the management of reputation and legitimacy: A cross sectorial analysis of UK top 100 companies. Bus. Ethnics Eur. Rev. 1999, 8, 5-13. [CrossRef]

62. Cruz, C.; Larraza-Kintana, M.; Garcés-Galdeano, L.; Berrone, P. Are Family Firms Really More Socially Responsible? Entrep. Theory Parct. 2014, 38, 1295-1316. [CrossRef]

63. Uhlaner, L.M. Business family as a team: Underlying force for sustained competitive advantage. Hand. Res. Fam. Bus. 2006, 125-144.

64. Déniz, M.D.L.C.D.; Suárez, M.K.C. Corporate social responsibility and family business in Spain. Bus. Ethnics 2005, 56, 27-41. [CrossRef]

65. Dunn, B. Family enterprises in the UK: A special sector. Fam. Bus. Rev. 1996, 9, 139-155. [CrossRef]

66. Neu, D.; Warsame, H.; Pedwell, K. Managing public impressions: Environmental disclosures in annual reports. Account. Org. Soc. 1998, 23, 265-282. [CrossRef]

67. Adams, C.A. Internal organisational factors influencing corporate social and ethical reporting: Beyond current theorizing. Account. Aud. Account. J. 2002, 15, 223-250. [CrossRef]

68. Prado-Lorenzo, J.M.; Gallego-Alvarez, I.; Garcia-Sanchez, I.M. Stakeholder engagement and corporate social responsibility reporting: The ownership structure effect. Corp. Soc. Resp. Environ. Manag. 2009, 16, 94-107. [CrossRef]

69. Bingham, J.B.; Dyer, W.G., Jr.; Smith, I.; Adams, G.L. A stakeholder identity orientation approach to corporate social performance in family firms. Bus. Ethics 2011, 99, 565-585. [CrossRef]

70. Marques, P.; Presas, P.; Simon, A. The Heterogeneity of Family Firms in CSR Engagement: The Role of Values. Fam. Bus. Rev. 2014, 27, 206-227. [CrossRef]

71. O'Boyle, E.H.; Rutherford, M.W.; Pollack, J.M. Examining the relation between ethical focus and financial performance in family firms: An exploratory study. Fam. Bus. Rev. 2010, 23, 310-326. [CrossRef]

72. Le Breton-Miller, I.; Miller, D. Socioemotional wealth across the family firm life cycle: A commentary on "Family Business Survival and the Role of Boards". Entrep. Theory Parct. 2013, 37, 1391-1397. [CrossRef]

73. Dobele, A.R.; Westberg, K.; Steel, M.; Flowers, K. An examination of corporate social responsibility implementation and stakeholder engagement: A case study in the Australian mining industry. Bus. Strategy Environ. 2014, 23, 145-159. [CrossRef]

74. Zellweger, T.M.; Nason, R.S.; Nordqvist, M.; Brush, C.G. Why do family firms strive for nonfinancial goals? An organizational identity perspective. Entrep. Theory Parct. 2013, 37, 229-248.

75. Micelotta, E.R.; Raynard, M. Concealing or revealing the family? Corporate brand identity strategies in family firms. Fam. Bus. Rev. 2011, 24, 197-216. [CrossRef]

76. Le Breton-Miller, L.; Miller, D. Agency vs. stewardship in public family firms: A social embeddedness reconciliation. Entrep. Theory Parct. 2009, 33, 1169-1191. [CrossRef]

77. Sundaramurthy, C.; Kreiner, G.E. Governing by managing identity boundaries: The case of family businesses. Entrep. Theory Parct. 2008, 32, 415-436. [CrossRef]

78. De Vries, M.F.K. The dynamics of family controlled firms: The good and the bad news. Organ. Dyn. 1994, 21, 59-71. [CrossRef]

79. Westhead, P.; Cowling, M.; Howorth, C. The development of family companies: Management and ownership imperatives. Fam. Bus. Rev. 2001, 14, 369-385. [CrossRef]

80. Bebbington, J.; Larrinaga, C.; Moneva, J.M. Legitimating reputation/the reputation of legitimacy theory. Account. Aud. Account. J. 2008, 21, 371-374. [CrossRef]

81. Global Reporting Initiative. Sustainability Reporting Guidelines, G3.1; Global Reporting Initiative: Amsterdam, The Netherlands, 2011.

82. Anderson, R.C.; Reeb, D.M. Founding-family ownership and firm performance: Evidence from the S\&P 500. J. Fin. 2003, 58, 1301-1328.

83. Croci, E.; Doukas, J.A.; Gonec, H. Family control and financing decisions. Europ. Financ. Manag. 2011, 17, 860-897. [CrossRef]

84. Faccio, M.; Lang, L.H.P. The ultimate ownership of Western Europe corporations. J. Financ. Econ. 2002, 65, 365-395. [CrossRef] 
85. Villalonga, B.; Amit, R. Family control of firms and industries. Financ. Manag. 2010, 39, 863-904. [CrossRef]

86. Guthrie, J.; Cuganesan, S.; Ward, L. Industry specific social and environmental reporting: The Australian Food and Beverage Industry. Account. For. 2008, 32, 1-15. [CrossRef]

87. Stavrou, E.; Kassinis, G.; Filotheou, A. Downsizing and Stakeholder Orientation among the Fortune 500: Does Family Ownership Matter? J. Bus. Ethics 2008, 72, 149-162. [CrossRef]

88. Brammer, S.; Pavelin, S. Factors influencing the quality of corporate environmental disclosure. Bus. Strategy Environ. 2008, 17, 120-136. [CrossRef]

89. Cheng, E.C.; Courtenay, S.M. Board composition, regulatory regime and voluntary disclosure. Int. J. Account. 2006, 41, 262-289. [CrossRef]

90. Naser, K.; Al-Hussaini, A.; Al-Kwari, D.; Nuseibeh, R. Determinants of corporate social disclosure in developing countries: The case of Qatar. Adv. Int. Account. 2006, 19, 1-23. [CrossRef]

91. Cormier, D.; Gordon, I.M.; Magnan, M. Corporate environmental disclosure: Contrasting management's perceptions with reality. Bus. Ethics 2004, 49, 143-165. [CrossRef]

92. Mio, C.; Venturelli, A. Non-financial information about sustainable development and environmental policy in the annual reports of listed companies: Evidence from Italy and the UK. Corp. Soc. Resp. Environ. Manag. 2013, 20, 340-358. [CrossRef]

93. Ho, S.S.; Wong, K.S. A study of the relationship between corporate governance structures and the extent of voluntary disclosure. J. Int. Account. Audit. Tax. 2001, 10, 139-156. [CrossRef]

94. Smith, A.C.; Westerbeek, H.M. Sport as a vehicle for deploying corporate social responsibility. J. Corp. Citiz. 2007, 25, 43-54. [CrossRef]

95. Namazi, M.; Namazi, N.R. Conceptual analysis of moderator and mediator variables in business research. Proc. Ecol. Financ. 2016, 36, 540-554. [CrossRef]

96. Zientara, P. Socioemotional wealth and corporate social responsibility: A critical analysis. Bus. Ethics 2015. [CrossRef]

97. Brown, N.; Deegan, C. The public disclosure of environmental performance information-A dual test of media agenda setting theory and legitimacy theory. Account. Bus. Res. 1998, 29, 21-41. [CrossRef]

98. Stavrou, E.T.; Swiercz, P.M. Securing the future of the family enterprise: A model of offspring intentions to join the business. Entrep. Theory Parct. 1998, 23, 19-21.

99. Block, J. Family management, family ownership, and downsizing: Evidence from S\&P 500 firms. Fam. Bus. Rev. 2010, 23, 109-130.

(C) 2016 by the authors; licensee MDPI, Basel, Switzerland. This article is an open access article distributed under the terms and conditions of the Creative Commons Attribution (CC-BY) license (http://creativecommons.org/licenses/by/4.0/). 